\title{
Sol Ana Koroner Arter Çıkış Anomalisi Olan Hasta
}

\author{
A Patient with an Anomalous Origin of the Left \\ Main Coronary Artery
}

\section{Özet}

Koroner arter anomalilerinin anjiyografik insidansı \%1,3'tür. Anjiyografık serilerde sol ana koroner arterin sağ sinüs Valsalva'dan orijin aldığı anomalilerin görülme sıklığı \%0,019 kadar düşüktür. Bu hastalarda yine nadiren (\%20 kadarında) anjina pektoris, aritmi, senkop, kalp krizi ve ani ölüm gibi semptomlar görülür. Burada, sağ sinüs Valsalva'dan orijin alan sol ana koroner arter anomalisi gibi nadir bir vakayı sunmaktayız.

Anahtar Sözcükler: koroner arter anomalileri; anjina pektoris

\section{Abstract}

The angiographic incidence of coronary anomalies is 1.3\%. The incidence of anomalies of the left main coronary artery originating from the right sinus of Valsalva is as low as $0.019 \%$ in angiographic series. Relatively few (about 20\%) of these patients develop symptoms such as angina pectoris, arrhythmias, syncope, myocardial infarction, or sudden death. We report here the unusual case of a patient with the left main coronary artery anomalously originating from the right sinus of Valsalva.

Keywords: coronary artery anomalies; angina pectoris
Mustafa Duran, Sani Murat

Ankara Eğitim ve Araştırma Hastanesi

Gelis Tarihi /Received : 24.04.2016 Kabul Tarihi /Accepted: 25.06.2016

Sorumlu Yazar/Corresponding Author Doç. Dr. Mustafa Duran

Ankara Eğitim ve Araştırma Hastanesi, Kardiyoloji Kliniği

E-mail:mduran2@gmail.com 


\section{VAKA}

47 yaşındaki erkek hasta hastanemiz acil servisine göğüs ağrısı şikayetiyle başvurdu. Hastanın ayrıca baş dönmesi ve bulantı şikayetleri de mevcuttu. Anamnezde hastanın hipertansiyonu ve sigara hikayesi olduğu da öğrenildi. Hastanın çekilen EKG’sinde sinüs bradikardisi, anteriyör derivasyonlarda bifazik $\mathrm{T}$ dalgaları izlendi. Ekokardiyografik incelemede hastada herhangi bir patoloji saptanmadi. Fizik muayenede kan basıncı 120/70 mmHg, nabız 50/dk ölçüldü. Hastanın şikayetlerinin giderek şiddetlendiğini belirtmesi üzerine koroner anjiyografi planland. Yapılan koroner anjiyografide sağ koroner arterde \%30 darlık izlendi. Sol ana koroner arter rutin incelemede görüntülenemedi; tanı için yapılan aortografide sol ana koroner arterin sağ sinüs Valsalva’dan çıktığı izlendi; selektif olarak sol ana koroner artere sağ sinüs Valsalva'dan yerleşilerek alınan görüntülemede ciddi bir lezyon saptanmadı (Figür 1). Hasta için medikal takip kararı verildi. Sol ana koroner arterin aort ve pulmoner arter arasından geçip geçmediğinin tespiti için hastaya çok kesitli bilgisayarlı tomografi çekilmesi planlandı. Ancak hasta bu tetkiki yaptırmak istemedi. Bunun üzerine hasta önerilerle taburcu edildi.

Anjiyografik serilerde koroner arter anomalisi görülme sıklığı \%1,3’tür ve sol ana koroner arterin sağ sinüs Valsalva'dan orijin aldığı anomalilerin görülme sıklığ $\% 0,019$ kadar düşüktür (1). Koroner arter anomalileri konjenital kap hastalıkları içeresinde daha sık görülürler, ileri yaş hasta grubunda daha az görülmekle birlikte çoğunlukla asemptomatik olduklarından hastalar genelde ileri yaşlarda tanı alırlar. Koroner anomaliler genellikle asemptomatiktir. Koroner arter anomalileri koroner ateroskleroz için bir risk faktö- rü değildirler ancak bu hastaların \%20'sinde sol ana koroner arterin sağ sinüs Valsalva'dan çıkıp sol tarafa ilerlerken asendan aort ile pulmoner arter arasindan geçmesi ve bu arada kompresyona maruz kalmasından dolayı anjina, kalp krizi, senkop ve ani kardiyak ölüm izlenebilir (2-4). Bu semptomlar özellikle efor nedeniyle meydana gelir; çünkü kan akımında efor s1rasinda azalma olur. Sol ana koroner arterin sağ sinüs Valsalva'dan çıkmasının klinik önemi, asıl olarak sol ana koroner arterin büyük arterler ile ilişkisine bağl1dır (5). Eğer aort ile pulmoner arter arasından geçmiyorsa genellikle ciddi mekanik kompresyon olmaz ve benign seyreder (1). Mekanik kompresyon olursa cerrahi tedavi de dahil hastanın tedavisi planlanmalıdır. Ayrıca bu tür koroner anomaliler damarlara girişimi de zorlaştırmaktadır. Rutinde kullandığımız guiding kateterler ile koroner anomalili damara oturmak zor olabilir ve girişim işlemi zorlaşabilir. Hasta kalp krizi şikayetiyle gelmişse işlem süresini uzatabilir ve başarı şansını düşürebilir. Damarın çıkış yerini gördükten sonra uygun guiding kateter seçimi ile işlem yapılabilir. Yine bu tür koroner arter anomalisi durumlarında anjina varlığında gereksiz koroner anjiyografi işlemi yapilabilmektedir. Sol ana koroner arterin büyük arterlerle ilişkisi göstermek için çok kesitli bilgisayarlı tomografi çekilebilir veya manyetik rezonans görüntüleme yapılabilir. Her iki tanı metodu da ayrıntılı olarak damarların çıkış yerini, büyük arterler ile ilişkisini ve daralma derecesini gösterebilir.

Sonuç olarak, nadir görülseler de koroner arter anomalileri özellikle genç hastalarda anjina nedeni olabilirler. Anomali görüldükten sonra koroner damarın seyrini tespit için ek incelemelere gerek vardır.
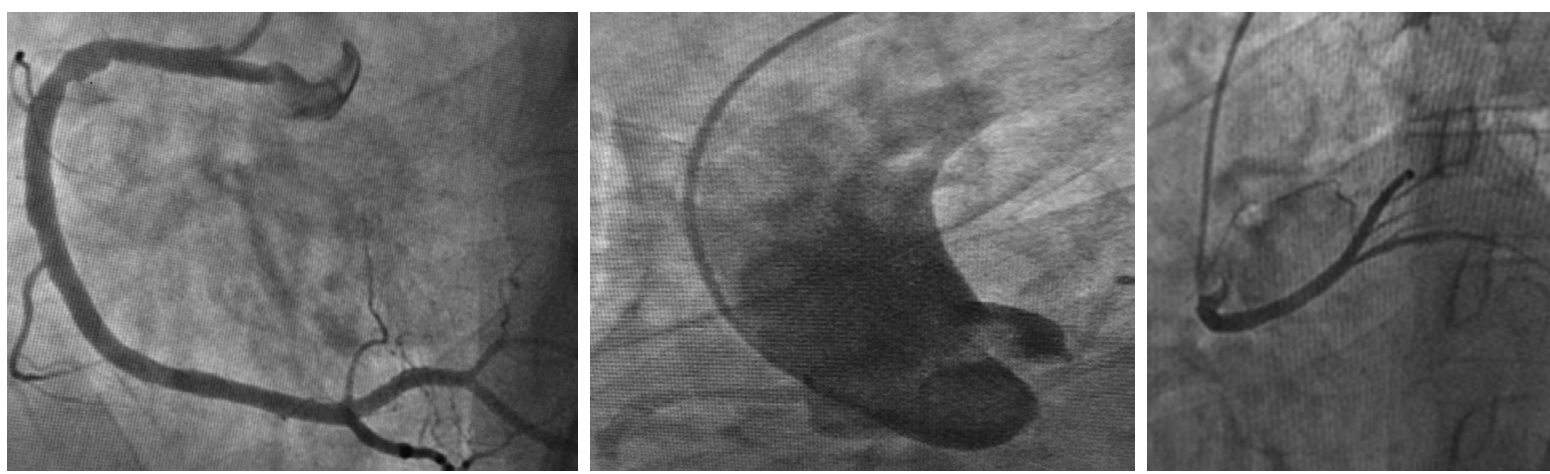

Figür 1. Soldan sağa; sağ koroner arter, aortografi, sağ sinüs Valsalva'dan çıkan sol ana koroner arter anomalisi. 


\section{KAYNAKLAR}

1. Angelini P. Coronary artery anomalies-current clinical issues: definitions, classification, incidence, clinical relevance, and treatment guidelines. Tex Heart Inst J. 2002; 29(4):271-8.

2. Duran M, Ornek E, Murat SN, Demircelik B, Vatankulu MA, Turfan M, et al. Coronary stenting for acute myocardial infarction in a patient with an anomalous origin of the left main coronary artery. J Cardiovasc Med (Hagerstown). 2011;12(6):436-8.3. Kastanis P, Marti V, Gotsanayidou M. Anomalous left coronary artery arising from the right sinus of Valsalva causing angina pectoris. J Cardiovasc Med 2009;10(7):574-5.
3. Trost B, Helperin JL. Unstable angina in a patient with anomalous origin of the left main coronary artery from the right sinus of Valsalva. Rev Cardiovasc Med. 2010;11(2):112-6.

4. Taylor AJ, Byers JP, CheitlinMD, Virmani R. Anomalous right or left coronary artery from the contralateral coronary sinus: "high-risk" abnormalities in the initial coronary artery course and heterogeneous clinical outcomes. Am Heart J. 1997;133(4):428-35. 